\title{
The Differences of Left Lateral and Head Elevation Position toward Heart Rate of Newborns with Asphyxia in the Perinatology Room RSUD Dr. Soediran Mangun Sumarso Wonogiri
}

\author{
Noerma Shovie Rizqiea ${ }^{1 *}$ (D), Septy Nur Aini ${ }^{2}$, Ratih Dwilestari Puji Utami ${ }^{1}$, Ratnawati Ratnawati3, Khairunisa Wardani ${ }^{3}$ \\ ${ }^{1}$ Department of Paediatric Nursing, Universitas Kusuma Husada Surakarta, Surakarta, Indonesia; ${ }^{2}$ Department of Paediatric \\ Nursing, Akademi Keperawatan Yappi Sragen, Sragen, Indonesia; ${ }^{3}$ Department of Paediatric, RSUD Dr. Soediran Mangun \\ Sumarso Wonogiri, Wonogiri, Indonesia
}

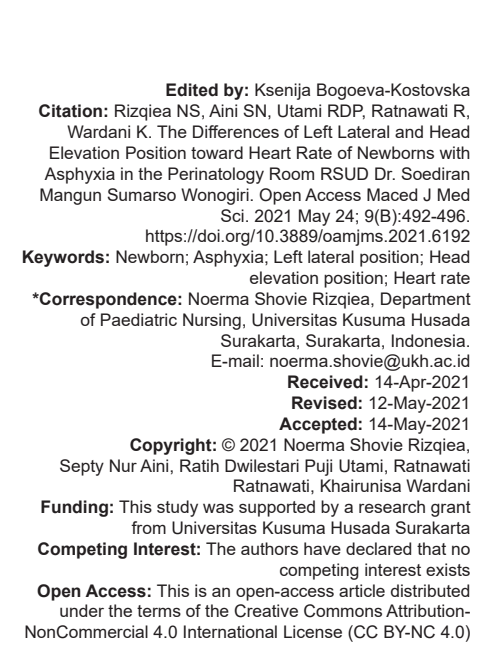

Introduction

Asphyxia causes hypoxic-ischemic encephalopathy and multiorgan failure. The organ most affected by hypoxia is the cardiovascular system. The hemodynamic instability occurs due to hypoxia, either in utero or during the newborn's resuscitation and transition causes other organs' effect. During delivery, the clinical focus during resuscitation of asphyxia infants is mostly to experience immediate heart rate changes and blood pressure [1]. Asphyxia births are assumed to be associated with intrapartum hypoxia-ischemia, which accounts for 1 million neonatal deaths annually. Asphyxia birth is also defined as a failure to initiate or maintain spontaneous breathing at birth [2]. Babies born with asphyxia experience a lack of oxygen (hypoxia) and have an increased heart rate (tachycardia) [3]. The determination of the heart rate is a basic assessment of the health of the newborns. It is a sensitive indicator for reference interventions during neonatal resuscitation and for accessing infants' clinical status. The ineffectiveness of the heart rate assessment significantly increases the risk of hypoxia and neonatal mortality [4].

The global number of neonatal deaths decreased from 5 million in 1990 to 2.5 million in 2018 . Every day there were 7000 deaths in 2018 compared to 14,000 in 1990 . Neonatal mortality accounted for $47 \%$ of all children under 5 in 2018 [5].

The World Health Organization states that children who die within the first 28 days of birth suffer from conditions and diseases associated with a lack of quality care at birth or skilled care and immediately after birth care and in the $1^{\text {st }}$ days of life. During 2019, there was $47 \%$ of under- 5 deaths occurred in the newborns period, with about a third dying on the day of birth and nearly three-quarters dying within the $1^{\text {st }}$ week of life. These neonatal deaths were caused by preterm birth, intrapartum-related complications (birth asphyxia or lack of breathing at birth), infections, and congenital defects account for most neonatal deaths [6]. 
Data from the Indonesian Data and Health Survey (IDHS) stated that in the 5 years before the 2017 IDHS, the neonatal mortality rate (NMR) was 15 deaths per 1000 live births, implying that one in 67 children died within the $1^{\text {st }}$ month of life. The 2017 IDHS showed the NMR decreased more than $31 \%$, from 35 per 1000 live births in the 2002-2003 IDHS to 24 per 1000 live births in the 2017 IDHS [7]. NMR in Central Java in 2018 was 6.1 per 1000 live births. The highest NMR was Rembang at 11.7 per 1000 live births, followed by Grobogan (11.5 per 1000 live births) and Banjarnegara (10.7 per 1000 live births). The district/ city with the lowest IMR was Surakarta city 1.8 per 1000 live births. The average of Central Java Province is 6.1 per 1000 live births. Meanwhile, Wonogiri Regency is 6.9 per 1000 live births, which means it is still higher than the average of Central Java. This NMR contributes to $73 \%$ of infant mortality in Central Java [8].

Management of the delivery room for newborns should be carried out according to international guidelines, but there are no recommendations which are available for positions of infants performed immediately after birth. The positions that are given to infants are supination, right tilt, and left tilt. The positions measured were the heart rate and oxygen saturation analyzed through the monitor at the $5^{\text {th }}$ and $8^{\text {th }}$ min. The results obtained were that at the $5^{\text {th }}$ and $8^{\text {th }}$ min for the heart rate, there was no significant change in the supination position, right tilt, and left tilt. Meanwhile, the oxygen saturation showed a significant difference in the right oblique or left oblique position compared to the $5^{\text {th }}$ and $8^{\text {th }}$ min supination positions [9].

The positions given to babies are left lateral, pronation, and supination. In the neonatal intensive care unit (NICU), the left lateral position can be used as an alternative for mild respiratory failure. Preliminary results show that breathing was normal for 30 min after changes in the baby's body position. Heart rate, respiration, and arterial blood pressure did not change significantly at all positions (left lateral, pronation, and supination). Although there was no significant change in the oxygen fraction at the three positions, the $\mathrm{SpO}_{2}$ was higher in the left lateral and pronation positions than in the supination position [10]. This study was conducted on two groups of infants, namely, infants with asphyxia and infants without asphyxia. Babies born with asphyxia are at risk for increased intracranial pressure. This study's finding was that babies who were given a head elevation position of $30^{\circ}$ could lower intracranial pressure [11]. Another study was divided into two groups: A group of infants given supination and pronation positions measured through a monitor over $15 \mathrm{~min}$. For the first $10 \mathrm{~min}$, there were measurements of $\mathrm{SpO}_{2}$, heart rate, and arterial blood gases $\left(\mathrm{ptcO}_{2}\right.$ and $\mathrm{ptcCO}_{2}$ ). It was then continued for another 5 min while the flow and pressure were recorded on the monitor. The supination and pronation positions did not show significant changes in lung function in infants with ventilator-attached respiratory distress syndrome [12].

The purpose of this research was to determine the difference in effect between the left lateral position and the head elevation position on the heart rate of newborns with asphyxia in the perinatology room RSUD Dr. Soediran Mangun Sumarso Wonogiri.

\section{Ethics approval}

Ethical clearance was carried out at the Health Research Ethics Commission of the Muhammadiyah University of Surakarta, with a letter number 2958/B.2/ KEPK-FKUMS/VI/2020.

\section{Materials and Methods}

The research method was a quasi-experimental research with a pre- and post-test non-equivalent control group design. The researcher used the quasi-type because it used two groups: The intervention group (left lateral position) and the control group (head elevation position). Moreover, the researcher conducted it from April 2020 to October 2020. The sampling technique used by researchers was non-probability sampling with a consecutive sampling method. This study samples were 60 babies, 30 babies included in the intervention group and 30 babies included in the control group. The inclusion criteria in this study were newborns aged $<24 \mathrm{~h}$ with mild asphyxia with appearance, pulse, grimace, activity, and respiration (APGAR) 7-10; newborns <24 h with moderate asphyxia with APGAR 4-6; newborns with a birth weight of more than $2500 \mathrm{~g}$ who received standard treatment, namely, babies treated in an incubator, inserted with D5 $1 / 4$ NS infusion, given $1 \mathrm{l} / \mathrm{min}$ nasal oxygen cannula; and parents who agreed that their babies were used as the research sample, as shown by the consent of the parents/guardians. At the same time, the exclusion criteria in this study were newborns aged $>1$ day; newborn with APGAR score 0-3 (severe asphyxia); babies with low birth weight (weight 1500-2500 g); babies with low birth weight (weight <1500 g); and newborns with the congenital disease (such as babies with congenital heart disease, down syndrome, anencephaly, hydrocephalus, omphalocele, diaphragmatic hernia, and duodenal atresia).

Administration of intervention occurred in the $1^{\text {st }}$ min of resuscitation, and analysis was carried out after the $1^{\text {st }}$ min. It stopped after 10 min or when the infant was finally removed from the resuscitation table (whichever comes first). The positions given to babies were the supination position, right tilt, and left tilt. The parameters measured were heart rate and oxygen saturation, analyzed through a monitor at the $5^{\text {th }}$ and $8^{\text {th }} \min [9]$. Meanwhile, the head elevation position was given at a $30^{\circ}$ position [11]. 
Researchers were assisted by research assistants, namely, nurses and doctors who worked at the hospital. The pediatrician had authority over the safety of assigning positions to newborns with asphyxia. The nurse, in this case, intervened in giving the left lateral position and head elevation position. The left lateral position and the head elevation position were given for $10 \mathrm{~min}$ in newborns with asphyxia. Measurement of heart rate changes was carried out before being given the left lateral position and head elevation position. After $10 \mathrm{~min}$, the measurement of the heart rate was carried out again in both positions.

\section{Results}

The study results were analyzed using the statistical program of Statistical Package for the Social Sciences version 20.0.

Table 1 shows the mothers' gestational age in the intervention group with a mean of $38.17 \pm 2.276$ weeks; the birth weight with a mean of $3022.07 \pm 460.962 \mathrm{~g}$. Meanwhile, the control group showed maternal gestational age with a mean of $38.30 \pm 1.236$ weeks and the birth weight with a mean of $2901.33 \pm 305.660 \mathrm{~g}$.

Table 1: The characteristics of the respondents $(n=60)$

\begin{tabular}{lllll}
\hline Intervention group $(\mathrm{n}=30)$ & & & & \\
\hline Mother's characteristics & Min. & Max. & Mean & Std. deviation \\
\hline Gestational age & 28 & 41 & 38.17 & 2.276 \\
Babies birth weight & 2200 & 4100 & 3022.07 & 460.962 \\
\hline Control group $(\mathrm{n}=30)$ & & & & \\
\hline Mother's characteristics & Min. & Max. & Mean & Std. deviation \\
\hline Gestational age & 37 & 41 & 38.30 & 1.236 \\
Babies birth weight & 2520 & 4000 & 2901.33 & 305.660 \\
\hline
\end{tabular}

Table 2 shows the frequency distribution of the neonate's heart rate with pre- and post-asphyxia getting the left lateral position and head elevation position. The paired t-test results of left lateral position showed $p=0.003(p<0.05)$, and the paired t-test results of head elevation position showed $p<0.001$ ( $p<0.05$ ), indicating a significant heart rate difference between before and after providing the left lateral position and head elevation position.

Table 3 shows the results of the independent t-test. $p=0.191(p \geq 0.05)$ so that there was no difference in heart rate between the group that got the left lateral position and the one who got the head elevation position.

\section{Discussion}

The left lateral position and the head elevation position were given for $10 \mathrm{~min}$ in newborns with asphyxia. Measurement of heart rate changes was carried out before being given the left lateral position and head elevation position. After $10 \mathrm{~min}$, the measurement of the heart rate was carried out again in both positions using pulse oximetry. Measurement of the heart rate using pulse oximetry was carried out after $10 \mathrm{~min}$ of a given position change [13]. Heart rate measurement is a vital assessment during resuscitation for newborns. Heart rate measurement can be done by auscultation/palpation, pulse oximetry, and electrocardiogram. Of the three measurements, pulse oximetry and electrocardiogram have better accuracy than using auscultation/palpation [4]. Another study stated that measuring the baby's heart rate during asphyxia was most accurate using Doppler ultrasound transducers positioned along the sternum and using the pulmonary or aortic valve examination mode. The use of this appliance was effective during infant asphyxia and resuscitation [14].

Characteristics of the respondents indicated that the youngest gestational age of mothers in the intervention group was 28 weeks and a greatest of 41 weeks with a mean of $38.17 \pm 2.276$; the smallest birth weight of $2200 \mathrm{~g}$ and a greatest of $4100 \mathrm{~g}$ with a mean of $3022.07 \pm 460.962$. Meanwhile, the control group showed a youngest maternal gestational age of 37 weeks and a greatest of 41 weeks with a mean of $38.30 \pm 1,236$; and smallest birth weight of $2520 \mathrm{~g}$ and a greatest of $4000 \mathrm{~g}$ with a mean of 2901.33 \pm 305.660 . There was no relationship between maternal gestational age and changes in the baby's heart rate at the time of giving the head elevation position $30^{\circ}$ [13].

The frequency distribution of the newborns heart rate with pre- and post-asphyxia got the left lateral position, and the results were the pre, smallest $128 \times / \mathrm{min}$, and greatest $170 \times / \mathrm{min}$ values. As for the post value, the smallest value was $136 \times / \mathrm{min}$, and the greatest value was $170 \times / \mathrm{min}$. The frequency distribution of the newborns heart rate with pre- and post-asphyxia got head elevation. The results obtained were the pre, smallest $100 \times / \mathrm{min}$, and greatest $170 \times / \mathrm{min}$ values. As for the post value, the smallest value is $130 \times / \mathrm{min}$, and the greatest value was $160 \times / \mathrm{min}$. Nurses might be able to take immediate action by reporting to the doctor if there was bradycardia $(<120 \times / \mathrm{min})$ or tachycardia $(>160 \times / \mathrm{min})$ on newborns with asphyxia [15]. The incidence of tachycardia could be increased by the incidence of asphyxia in newborns [3]

Heart rate before and after given left lateral position. The paired t-test results showed $p=0.003$

Table 2: The analysis of neonates heart rate with asphyxia pre- and post-test got left lateral position and head elevation position $(n=60)$

\begin{tabular}{|c|c|c|c|c|c|c|c|c|}
\hline Variable & Group & Min & $\operatorname{Max}$ & Mean of pre-test & Mean of post-test & Mean difference (s.b) & Std. deviation & $\mathrm{p}$-value \\
\hline Heart rate & $\begin{array}{l}\text { Intervention group }(n=30) \\
\text { Control group }(n=30)\end{array}$ & $\begin{array}{l}128(136) \\
100(130)\end{array}$ & $\begin{array}{l}170(170) \\
170(160)\end{array}$ & $\begin{array}{l}139.73 \\
128.10\end{array}$ & $\begin{array}{l}143.93 \\
146.20\end{array}$ & $\begin{array}{l}4.2(6.975) \\
18.1(16.121)\end{array}$ & $\begin{array}{l}12.202-7.492 \\
16.346-5.641\end{array}$ & $\begin{array}{l}0.003 \\
<0.001\end{array}$ \\
\hline
\end{tabular}


Table 3: Independent t-test analysis of neonates heart rate with asphyxia pre- and post-test got left lateral position and head elevation position $(n=60)$

\begin{tabular}{llll}
\hline Variable & Average $(\mathrm{s} . \mathrm{b})$ & $\mathrm{p}$-value & Mean difference (IK 95\%) \\
\hline $\begin{array}{l}\text { Heart rate after left lateral } \\
\text { positioning }(\mathrm{n}=30)\end{array}$ & $143.93(7.492)$ & 0.191 & $-2.267(-5.694-1.161)$ \\
$\begin{array}{l}\text { Heart rate after head } \\
\text { elevation positioning }(\mathrm{n}=30)\end{array}$ & $146.20(5.641)$ & & \\
\hline
\end{tabular}

$(p<0.05)$, indicating a significant difference in heart rate between before and after giving the left lateral position. The paired t-test results showed a value of $p<0.001$ $(p<0.05)$, thus indicating a significant difference in heart rate between before and after giving the position of head elevation. The independent t-test results obtained $p=0.191$ $(p \geq 0.05)$ so that there was no difference in heart rate between the groups who got the left lateral position and those who got the head elevation position. The practice of giving positions to babies in the NICU room to reduce the incidence of intraventricular hemorrhage, there were several suggested positions, and the most potential is to offer a middle position and a bed elevation of $30^{\circ}$ [16].

Experiments in the lateral, right lateral, and pronation positions before providing food for premature infants ( $\leq 34$ weeks) obtained comparable heart rate and oxygen saturation results in these three positions [17]. Other studies comparing the way premature babies (pronation, supination, and left lateral) obtained normal heart rate results at these three positions, only slightly better in the pronation position [18].

\section{Conclusion}

Both of the positions have a significant change in newborns' heart rate with asphyxia. There was no significant difference in newborns' heart rate with asphyxia in the both of the position.

\section{Acknowledgments}

The researchers acknowledge the contribution of all parties involved in this research and the contribution of Center for Research and Community Service of Universitas Kusuma Husada Surakarta for funding this study.

\section{References}

1. Polglase GR, Ong T, Hillman NH. Cardiovascular alterations and multi organ dysfunction after birth asphyxia. Clin Perinatol.,
2016;43(3):469-83. https://doi.org/10.1016/j.clp.2016.04.006 PMid:27524448

2. Moshiro R, Mdoe P, Perlman JM. A global view of neonatal asphyxia and resuscitation. Front Pediatr. 2019;7:489. https:// doi.org/10.3389/fped.2019.00489

PMid:31850287

3. Cohen G, Katz-Salamon M, Malcolm G. A key circulatory defence against asphyxia in infancy the heart of the matter! J Physiol. 2012;590(23):6157-65. https://doi.org/10.1113/ jphysiol.2012.239145

PMid:23006482

4. Johnson PA, Schmölzer GM. Heart rate assessment during neonatal resuscitation. Healthcare. 2020;8(1):43. https://doi. org/10.3390/healthcare8010043

PMid:32102255

5. UNICEF, World Health Organization. World Bank: UN DESA Levels and Trends in Child Mortality 2019. UN IGME Rep. Geneva: World Health Organization; 2019. p. 52.

6. World Health Organization. WHO Newborns Improving Survival and Well-being. Geneva: World Health Organization; 2020. Available from: https://www.who.int/news-room/fact-sheets/ detail/newborns-reducing-mortality. [Last accessed on 2021 Feb 10]

7. BKKBN. Badan Pusat Statistik, Kementerian Kesehatan, and IFC International, Survei Demografi dan Kesehatan Indonesia 2017; 2017.

8. Jateng D. Profil Kesehatan Provinsi Jawa Tengah Tahun 2018; 2018. Available from: http://www.dinkesjatengprov.go.id. [Last accessed on $2021 \mathrm{Feb} 10]$.

9. Konstantelos D, Gurth H, Bergert R, Ifflaender S, Rüdiger M Positioning of term infants during delivery room routine handling analysis of videos. BMC Pediatr. 2014;14(1):33. https://doi. org/10.1186/1471-2431-14-33 PMid:24495525

10. Gouna G, Rakza T, Kuissi E, Pennaforte T, Mur S, Storme L. Positioning effects on lung function and breathing pattern in premature newborns. J Pediatr. 2013;162(6):1133-7.e1. https:// doi.org/10.1016/j.jpeds.2012.11.036 PMid:23312684

11. Emery JR, Peabody JL. Head position affects intracranial pressure in newborn infants. J Pediatr. 1984;103(6):950-3. PMid:6644434

12. Vendettuoli V, Veneroni C, Zannin E, Mercadante D, Matassa P Pedotti A, et al. Positional effects on lung mechanics of ventilated preterm infants with acute and chronic lung disease. Pediatr Pulmonol. 2015;50(8):798-804. https://doi.org/10.1002/ppul.23049 PMid:24706414

13. Fister $\mathrm{P}$, Nolimal $\mathrm{M}$, Lenasi $\mathrm{H}$, Klemenc $\mathrm{M}$. The effect of sleeping position on heart rate variability in newborns. BMC Pediatr. 2020;20(1):156. https://doi.org/10.1186/s12887-020-02056-2 PMid:32284055

14. Morina N, Johnson PA, O'Reilly M, Lee TF, Yaskina M, Cheung PY, et al. Doppler ultrasound for heart rate assessment in a porcine model of neonatal asphyxia. Front Pediatr. 2020;8:18. https://doi.org/10.3389/fped.2020.00018 PMid:32083045

15. Borzie K, Jasper N, Southall DP, MacDonald R, Kola AA, Dolo O, et al. Monitoring intrapartum fetal heart rates by mothers in labour in two public hospitals: An initiative to improve maternal and neonatal healthcare in Liberia. BMC Pregnancy Childbirth. 2020;20(1):362. https://doi.org/10.1186/s12884-020-02921-z PMid:32536345

16. Malusky S, Donze A. Neutral head positioning in premature infants for intraventricular hemorrhage prevention: An 
evidence-based review. Neonatal Netw. 2011;30(6):381-96. https://doi.org/10.1891/0730-0832.30.6.381

\section{PMid:22052118}

17. Kaur V, Kaur R, Saini SS. Comparison of three nursing positions for reducing gastric residuals in preterm neonates: A randomized crossover trial. Indian Pediatr. 2018;55(7):568-72. https://doi. org/10.1007/s13312-018-1298-0

PMid:30129537

18. Rad ZA, Mojaveri MH, Hajiahmadi M, Ghanbarpour A, Mirshahi S. Effects of position on oxygen saturation and heart rate in very low birth weight neonates. Casp J Pediatr. 2016;2(2):153-7. 